Original Paper

\title{
Peningkatan Kemampuan Guru dalam Menyusun Soal Evaluasi Melalui Kegiatan In House Training (IHT)
}

\author{
Mubassyiratul Ayuni ${ }^{{ }^{*}}$ \\ ${ }^{1}$ Sekolah Dasar Negeri 16 Mataram, Indonesia.
}

*Corresponding Author: Mubassyiratul Uyuni,

Sekolah Dasar Negeri 16 Mataram, Indonesia;

Email:

ayoeazkirania@gmail.com

\begin{abstract}
Abstrak: Kemampuan guru SDN 24 Mataram dalam menuyusun soal evaluasi yag baik masih dikatakan rendah. Soal-soal yang disusun guru belum sesuai dengan kaidah penulisan soal. Tujuan penelitian ini adalah untuk meningkatkan kemampuan guru dalam menyusun soalevaluas melalui kegiatan In House Training (IHT). Penelitian ini terdiri dari 2 siklus yaitu siklus I dan siklus II. Penelitian dilaksanakan di SDN 24 Mataram pada bulan Agustus sampai bulan September 2018. Subyek penelitian tindakan sekolah ini yaitu guru-guru SDN 24 Mataram dengan jumlah guru sebanyak 11 orang. Sumber data dalam penelitian ini adalah guru, kepala sekolah, dan catatan lapangan oleh peneliti. Hasil penelitian menunjukkan bahwa pada siklus I, setelah kegiatan IHT terdapat 9 peserta $(81,81 \%)$ memperoleh kriteria kurang memahami, 2 peserta $(18,18 \%)$ memperoleh kriteria memahami dan $0 \%$ tidak memahami, kategori capaian masuk dalam kategori krang memahami dengan nilai capaian rata-rata $68,64 \%$. Pada siklus II menunjukkan 2 peserta (18.18\%) masuk dalam kriteria kurang memahami, 9 peserta $(81.81 \%)$ mask dalam kriteria memahami dan 0 peserta $(0 \%)$ tidak memahami, kategori rata-rata capaian masuk dlaam kategori memahami dengan nilai capaian rata-rata $80.90 \%$. Dengan demikian dapat disimpulkan bahwa terjadi peningkatan yang cukup signifikan walaupun belum $100 \%$.
\end{abstract}

Kata Kunci: Peningkatan kemampuan guru; soal evaluasi; In House Training (IHT)

\section{Pendahuluan}

Menurut Permendiknas No.16 Tahun 2007, salah satu kompetensi pedagogik yang melekat pada profesi guru adalah menyelenggarakan penilaian dan evaluasi proses dan hasil belajar serta memanfaatkan hasil penilaian dan evaluasi untuk kepentingan pembelajaran. Rumusan kompetensi guru tersebut menjelaskan bahwa selain megajar harus melakukan penilaian pembelajaran. Astuti, (2017) menjalskan bahwa penilaian harus dilakukan dengan tahapan awal yaitu memahami hakikat penilaian, memahami cakupan ranah atau aspek yang dinilai, merancang prosedur penilaian, menyusun instrumen, melaksanakan penilaian, mengadministrasikan hasil, mengolah hasil, melaporkan hasil dan menggunakan hasil penilaian untuk melakukan pembinaan siswa dan memperbaiki pembelajaran.

Penilaian adalah penerapan berbagai cara dan penggunaan beragam alat, untuk memperoleh berbagai informasi ketercapaian kompetensi peserta didik. Osnal, dkk (2016) menjelaskan bahwa penilaian pada dasarnya bertujuan untuk mendapatkan informasi tentang perkembangan proses dan hasil belajar para peserta didik dan hasil mengajar guru. Informasi hasil penilaian ini dapat digunakan sebagai sarana untuk memotivasi peserta didik dalam pencapaian kompetensi dasar, melaksanakan program remidial serta mengevaluasi kemampuan guru dalam rangka meningkatkan kualitas pembelajaran.

Hasil penilaian yang baik sangat bergantung kepada kemampuan guru dalam menyusun soal. Menyusun soal bertujuan untuk mengukur keberhasilan siswa dalam menguasai indikatorindikator kompetensi dasar yang sudah diajarkan. Menurut Osnal, dkk (2016) hasil evaluasi akan menjelaskan letak kekurangan siswa selama proses pembelajaran. Menyusun soal evaluasi yang memenuhi persyaratan cukup sulit karena 
menyusun soal evaluasi memerlukan pengetahuan, keterampilan serta ketelitian yang cukup tinggi.

Berdasarkan pengamatan di sekolah, penulis banyak menemukan soal-soal yang disusun guru belum sesuai dengan kaidah penulisan soal, misalnya dari segi tata bahasa soal belum menggunakan ejaan Bahasa Indonesia yang disempurnakan (EYD), pilihan jawaban dalam soal pilihan ganda belum homogen, konstruksi soal belum dirumuskan secara jelas dan tegas, dan sebagainya. Soal-saol tersebut dibuat untuk kegiatan ulangan harian, ulangan tengah semester dan akhir semester dan hasilnya menjadi penentu kelulusan peserta didik.

Selain itu, kenyataan yang terjadi di sekolah bahwa guru belum mampu menyusun tes dengan baik. Biasanya menggunakan tes yang sudah ada kemudian disesuaikan dengan materi ajarnsehingga sering terjadi tidak tepat antara soal dengan kompetensi dasar yang disyaratkan dalam Kurikulum. Menurut Nazaruddin, (2018) sebagian besar guru belum bisa menyusun soal, sehingga sering mencari dari beberapa kumpulan soal yang sudah ada. Setiap penyelenggaraan ulangan akhir semester kadang-kadang tes tersebut secara utuh dapat ditampilkan lagi pada semester berikutnya.

Sangat disayangkan ketika hasil evaluasi peserta didik yang kurang memuaskan seringkali diangap menjadi kesalahan peserta didik oleh guru tanpa mengevaluasi terlebih dahulu apakah soal yang diberikan kepada peserta didik sudah baik apa tidak. Inilah yang menjadi permasalahan besar guru yaitu minimnya kemampuannya dalam menysun soal evaluasi.

Berdasarkan latar belakang di atas penulis tertarik untuk mengkaji secara lebih mendalam tentang peningkatan kemampuan guru dalam menyusun soal evaluasi. Untuk permasalahan tersebut maka penulis melakukan penelitian tindakan sekolah (PTS) dengan judul "Upaya meningkatkan kemampuan guru dalam menyusun soal evaluasi melalui wKegiatan In House Training (IHT)".

\section{Metode}

Penelitian ini menggunakan Penelitian Tindakan. Penelitian tindakan meliputi: (a) perencanaan tindakan berdasarkan kepada permasalahan yang dihadapi; (b) pelaksanaan tindakan; (c) pengamatan dan pengumpulan data; (d) analisis data hasil penelitian; (e) refleksi (perenungan) hasil analisis; (f) perubahan/revisi perencanaan untuk pengembangan selanjutnya. Penelitian ini terdiri dari 2 siklus yaitu siklus I dan siklus II. Penelitian dilaksanakan di SDN 24 Mataram pada bulan Agustus sampai bulan September 2018.

Subyek penelitian tindakan sekolah ini yaitu guru-guru SDN 24 Mataram dengan jumlah guru sebanyak 11 orang. Sumber data dalam penelitian ini adalah guru, kepala sekolah, dan catatan lapangan oleh peneliti. Kriteria yang digunakan dalam mengukur hasil kemampuan peserta IHT adalah: $80 \%-100 \%=$ Memahami $(\mathrm{M}), 56 \%$ $79 \%=$ Kurang Memahami $(\mathrm{KM})$, dan $<55 \%=$ Tidak Memahami (TM).

\section{Hasil dan Pembahasan}

Sebelum kegiatan In House Training dilaksanakan, terlebih dahulu dilaksanakan pree test kepada peserta. Soal pree test ini dimaksudkan untuk mengetahui sejauh mana peserta menguasai materi yang disampaikan pada kegiatan In house Training. Setelah kegiatan pree test dilanjutkan dengan pemaparan materi sampai dengan penyusunan soal evaluasi berdasarkan kaidahkaidah penyusunan soal dari kisi-kisi soal yang telah dibuat oleh peserta, kemudian peserta memaparkan hasil penyusunan soal evaluasi dan kisi-kisi soal yang dibuatnya yang hasilnya langsung dievaluasi oleh nara sumber.

Untuk melihat dan mengetahui tingkat pencapaian hasil pelaksanaan program, maka dilakukan monitoring dan evaluasi kegiatan. Pelaksanaannya dilakukan secara rutin selama seminggu. Kegiatan monitoring dan evaluasi kegiatan IHT penyusunan soal evaluasi ini dilakukan dengan cara observasi langsung yang dilakukan oleh Kepala SDN 24 Mataram. Hal ini dimaksudkan untuk meminimalkan dan mengantisipasi segala kemungkinan yang akan terjadi yang dapat menghambat pencapaian tujuan program.

Berdasarkan hasil perhitungan dan instrumen monitoring dan evaluasi kegiatan IHT diperoleh hasil pre test dan post test hasil seperti Tabel 1: 
Tabel 1: Rekap Hasil Pre Test Dan Post Test Siklus I

\begin{tabular}{|c|c|c|c|c|c|c|c|}
\hline \multirow{3}{*}{ No. } & \multirow{3}{*}{ Nama Guru } & \multicolumn{6}{|c|}{ Skor / Nilai } \\
\hline & & \multicolumn{3}{|c|}{ Pre Test } & \multicolumn{3}{|c|}{ Pos Test } \\
\hline & & Skor & Nilai & Kategori & Skor & Nilai & Kategori \\
\hline 1 & Peserta 1 & 10 & 50.00 & $\mathrm{TM}$ & 13 & 65.00 & $\mathrm{KM}$ \\
\hline 2 & Peserta 2 & 11 & 65.00 & KM & 14 & 70.00 & KM \\
\hline 3 & Peserta 3 & 9 & 45.00 & TM & 12 & 60.00 & KM \\
\hline 4 & Peserta 4 & 15 & 75.00 & $\mathrm{KM}$ & 16 & 80.00 & M \\
\hline 5 & Peserta 5 & 13 & 65.00 & KM & 15 & 80.00 & M \\
\hline 6 & Peserta 6 & 10 & 50.00 & TM & 13 & 65.00 & KM \\
\hline 7 & Peserta 7 & 13 & 65.00 & KM & 15 & 75.00 & KM \\
\hline 8 & Peserta 8 & 10 & 50.00 & TM & 12 & 60.00 & $\mathrm{KM}$ \\
\hline 9 & Peserta 9 & 13 & 65.00 & KM & 14 & 70.00 & KM \\
\hline \multirow[t]{3}{*}{10} & Peserta 10 & 11 & 55.00 & TM & 14 & 70.00 & KM \\
\hline & Jumlah & - & 640.00 & & - & 760.00 & \\
\hline & Rata-rata & - & 58,18 & KM & - & 69.09 & $\mathrm{KM}$ \\
\hline
\end{tabular}

Berdasarkan Tabel 1, hasil pre test menunjukkan rata-rata kategori KM (Kurang Memahami), 6 peserta $(54,54 \%)$ tidak memahami dan 5 peserta $(45,45 \%)$ kurang memahami dengan nilai capaian rata-rata $58,18 \%$ degan predikat $\mathrm{KM}$. Sedangkan hasil post test setelah kegiatan IHT menunjukkan 8 peserta $(81,81 \%)$ Kurang
Memahami, 2 peserta $(18,18 \%)$ memahami dan $0 \%$ tidak memahami, kategori capaian KM ( Kurang Memahami) dengan nilai capaian rata-rata $68,64 \%$. Terjadi sedikit peningkatan namun belum signifikan. Dalam bentuk Grafik dijelaskan seperti Gambar 1.

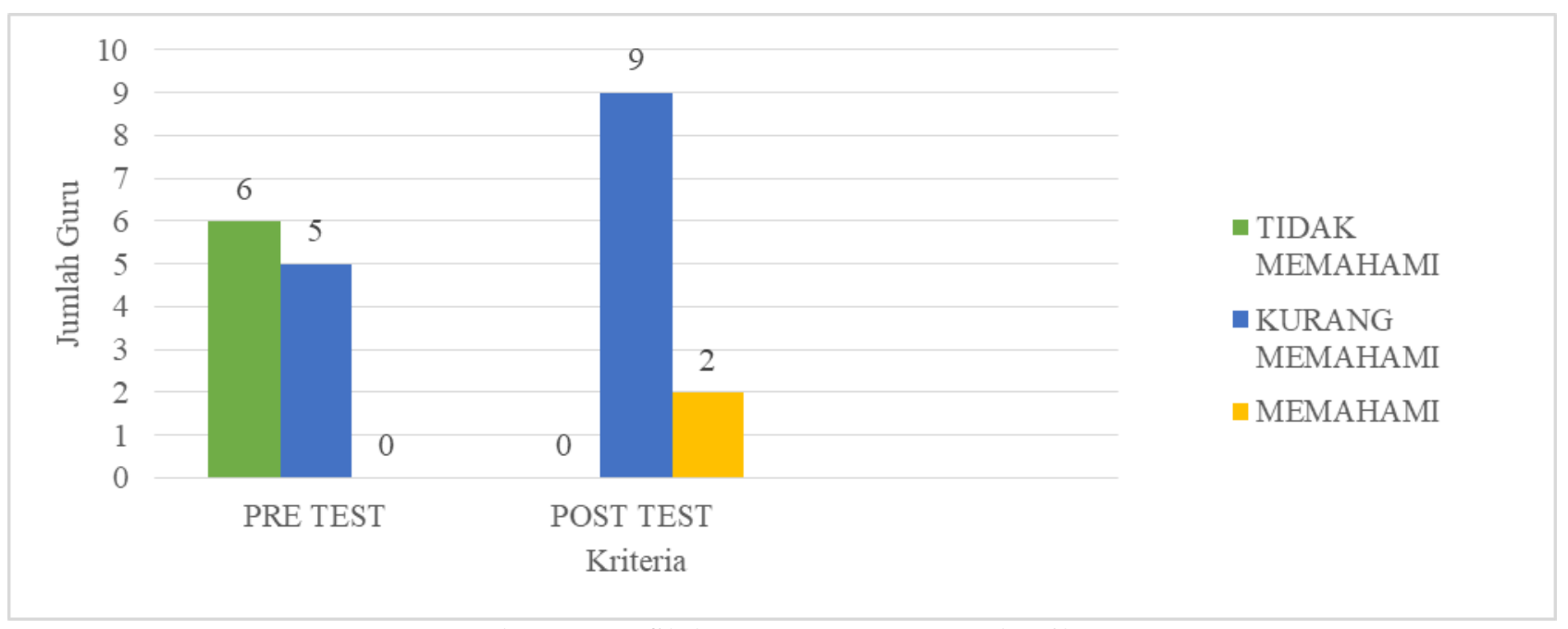

Gambar 1: Grafik kemampuan Guru pada Sikus I

Persiapan dalam siklus II adalah lanjutan hasil refleksi pada siklus pertama. Hal-hal apa saja yang masih kurang diperbaiki dan yang sudah baik dipertahankan. Kegiatan yang dilakukan pada tahap persiapan siklus kedua adalah: 1) Membuat rencana kembali perbaikan pelaksanaan kegiatan, 2) Mengkomunikasikan rencana tindakan perbaikan dengan kepala sekolah, 3) Mengundang kembali guru dan TAS untuk rapat kerja untuk rencana perbaikan pelaksanaan, dan 4) Memperbaiki dokumen yang ada.

Tahap pelaksanaan pada siklus II dilakukan dengan mengembangkan hasil IHT pada siklus 1, yang sudah baik dipertahankan dan yang masih kurang ditingkatkan. Dalam kegiatan penyusunan soal evaluasi melalui kegiatan IHT siklus I, guru belum $100 \%$ memahami cara penyusunan kisi-kisi, masih ada guru yang kurang memahami penyusunan soal evaluasi yakni sebanyak 9 dari 11 
orang guru. Bagi guru yang sudah memahami, kemampuannya dikembangkan lagi dengan menyusun kisi-kisi soal dan soal evaluasi Ulangan Tengah Semester ganjil Tahun pelajaran 2018/2019.

Untuk melihat dan mengetahui tingkat pencapaian hasil pelaksanaan program, maka dilakukan kembali monitoring dan evaluasi kegiatan. Pelaksanaannya dilakukan secara rutin dan berkala dengan tujuan untuk meminimalkan dan mengantisipasi segala kemungkinan yang akan terjadi pada siklus II yang dapat menghambat pencapaian tujuan program. Pada siklus II ini monitoring dilakukan dengan cara observasi langsung keterlaksanaan IHT oleh Kepala SDN 24 Mataram sebagai fasilitator.

Berdasarkan hasil perhitungan dan evaluasi kegiatan IHT diperoleh hasil pre test dan post test seperti Tabel 2:

Tabel 2. Rekap Hasil Pre Test Dan Post Test Siklus II

\begin{tabular}{|c|c|c|c|c|c|c|c|}
\hline \multirow{3}{*}{ No. } & \multirow{3}{*}{ Nama Guru } & \multicolumn{6}{|c|}{ Skor / Nilai } \\
\hline & & \multicolumn{3}{|c|}{ Pre Test } & \multicolumn{3}{|c|}{ Pos Test } \\
\hline & & Skor & Nilai & Kategori & Skor & Nilai & Kategori \\
\hline 1 & Peserta 1 & 16 & 80.00 & M & 16 & 80.00 & M \\
\hline 2 & Peserta 2 & 13 & 65.00 & KM & 16 & 80.00 & M \\
\hline 3 & Peserta 3 & 13 & 65.00 & $\mathrm{KM}$ & 15 & 75.00 & $\mathrm{KM}$ \\
\hline 4 & Peserta 4 & 16 & 80.00 & M & 18 & 90.00 & M \\
\hline 5 & Peserta 5 & 16 & 80.00 & M & 17 & 85.00 & M \\
\hline 6 & Peserta 6 & 13 & 65.00 & $\mathrm{KM}$ & 16 & 80.00 & M \\
\hline 7 & Peserta 7 & 15 & 75.00 & KM & 17 & 85.00 & M \\
\hline 8 & Peserta 8 & 14 & 70.00 & $\mathrm{KM}$ & 15 & 75.00 & $\mathrm{KM}$ \\
\hline 9 & Peserta 9 & 15 & 75.00 & $\mathrm{KM}$ & 16 & 80.00 & $\mathrm{M}$ \\
\hline 10 & Peserta 10 & 15 & 75.00 & $\mathrm{KM}$ & 16 & 80.00 & M \\
\hline \multicolumn{2}{|c|}{ Jumlah } & & 800.00 & & - & 890.00 & \\
\hline \multicolumn{2}{|c|}{ Rata-Rata } & - & 72,72 & KM & - & 80.90 & $\mathrm{M}$ \\
\hline
\end{tabular}

Berdasarkan Tabel 2, hasil pre test menunjukkan 7 peserta $(72,72 \%)$ kurang memahami, 3 peserta $(27,27 \%)$ memahami, dan 0 peserta ( $0 \%)$ tidak memahami dengan nilai capaian rata-rata $72,27 \%$ dengan predikat kurang memuaskan. Sedangkan hasil post test setelah kegiatan IHT pada siklus 2 menunjukkan 2 peserta
(18.18\%) Kurang Memahami, 8 peserta $(81.81 \%)$ memahami dan 0 peserta $(0 \%)$ tidak memahami, kategori rata-rata capaian memuaskan dengan nilai capaian rata-rata $80.90 \%$. Terjadi peningkatan yang cukup signifikan walau belum $100 \%$. Dalam bentuk Grafik dijelaskan seperti Gambar 2.

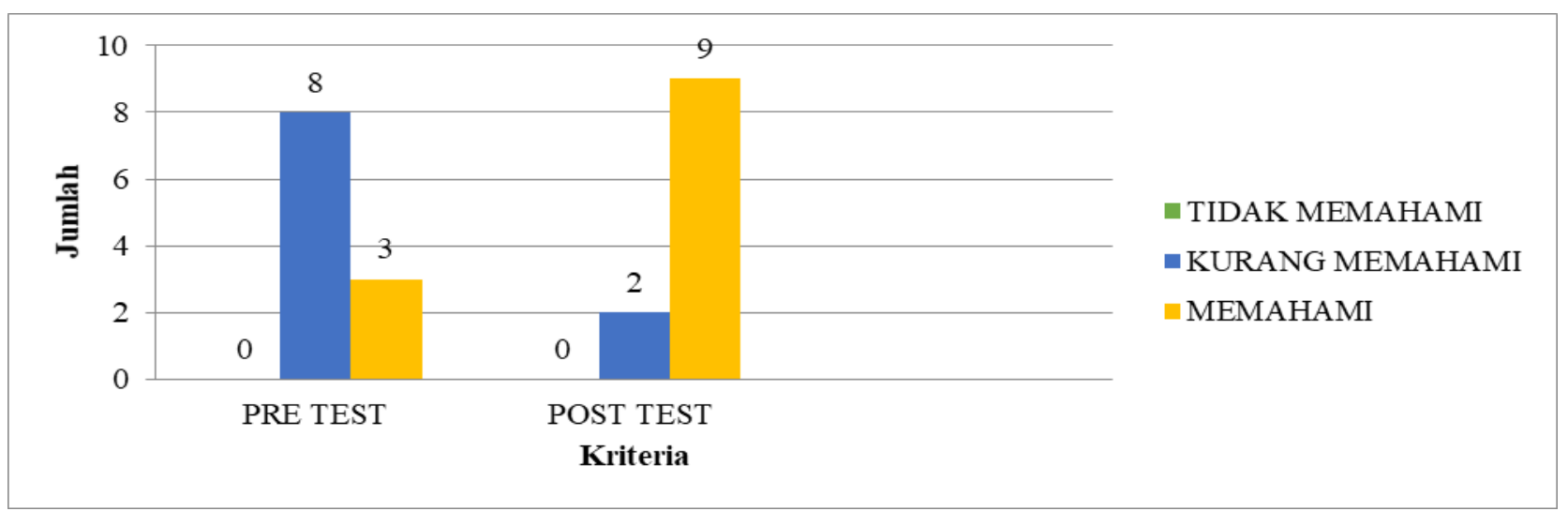

Gambar 2. Grafik kemampuan Guru pada Sikus II 
Hasil pre test pada siklus kedua ini menunjukkan 7 peserta $(72,72 \%)$ Kurang Memahami, 3 peserta $(27,27 \%)$ memahami, dan 0 peserta ( $0 \%$ ) tidak memahami dengan nilai capaian rata-rata $72,27 \%$ dengan predikat KM. Sedangkan hasil post test setelah kegiatan IHT pada siklus 2 menunjukkan 2 peserta $(18.18 \%)$ Kurang Memahami, 8 peserta $(81.81 \%)$ memahami dan 0 peserta $(0 \%)$ tidak memahami, kategori rata-rata capaian M (Memahami) dengan nilai capaian ratarata $80.90 \%$. Terjadi peningkatan yang cukup signifikan walau belum $100 \%$.

\section{Kesimpulan}

Berdasarkan hasil penilaian pre test dan post test terhadap hasil penyusunan kisi-kisi soal dan soal evaluasi yang telah dibuat guru-guru SDN 24 Mataram berdasarkan kegiatan penyusunan soal evaluasi melalui IHT dapat disimpulkan bahwa terjadi peningkatan hasil yang signifikan dari hasil siklus I dengan siklus ke 2. Hasil dari penyusunan kisi-kisi soal dan penyusunan soal evaluasi melalui kegiatan In House Training (IHT) dapat digunakan oleh guru-guru SDN 24 Mataram sebagai soal evaluasi Ulangan Tengah Semester ganjil pada tanggal 24 s/d 29 September 2018 Tahun pelajaran 2018/2019.

\section{Daftar Pustaka}

Astuti, S, Slameto, Dwikurnaningsih, Y,. 2017. Peningkatan Kemampuan Guru Sekolah Dasar Dalam Penyusunan Instrumen Ranah Sikap Melalu In House Training. Jurnal Manajemen Pendidikan. 4(1), hal. 37-47

Nazaruddin. 2017. Kemampuan Guru dalam Menyusun Tes Hasil Belajar melalui Workshop di SD Negeri Lamteubee. Serambi Akademica. 5(1).

Osnal, Suhartoni, Imam Wahyudi. 2016. Meningkatkan Kemampuan Guru dalam Menyusun Tes Hasil Belajar Akhir Semester Melalui Workshop Di KKG Gugus 02 Kecamatan Sumbermalang Tahun 2014/2015. Pancaran. 5(1), hal 67-82
Permendiknas. 2007. Peraturan Menteri Pendidikan Nasional No. 16 Tahun 2007 tentang Standar Kompetensi Guru. Jakarta: Depdiknas. 